\title{
Management of Organizational Culture in the Public Institutions of Ecuador Educational Sector
}

\author{
DOI: 10.12776/QIP.V22I1.1044 \\ Mayra Mercedes Marcillo Indacochea, Raúl Ricardo Fernández \\ Concepción, Angie Fernández Lorenzo
}

Received: 08 December 2017 Accepted: 27 February 2018 Published: 31 March 2018

\begin{abstract}
Purpose: The current study has, as its fundamental objective, the conceptual analysis of organizational culture management models that could be applied in public institutions of the education sector, as well as on management models of the organizational culture mainly those aimed at providing customer services in this sector.
\end{abstract}

Methodology/Approach: It was made an analysis of the main models that exist, and the possibility of adapting them to public institutions in the educational sector, which will improve the management of the organizational culture, according to processes that take place within them.

Findings: The non-existence of organizational culture management models aimed at providing customer services in public institutions of the educational sector was identified, as well as the complexity of applying other models of organizational culture management in institutions of the sector referred to from the gaps that they present.

Research Limitation/implication: The analyzed models are directed to private and public companies, they do not present methodological frameworks of action beyond the elaboration of business strategies, that allow to be applied directly in organizations with academic aims.

Originality/Value of paper: The document was based on the literary review of management of the organizational culture, in which it was detected that the models studied are aimed at companies, being complex their adaptation for institutions of the educational sector. No references were found about management models of the organizational culture focused on the provision of services to the client, which brings novelty to future research.

Category: Literature review 
Keywords: management; organizational culture; model; public institutions

\section{INTRODUCTION}

In former studies, it is exposed that the organizational culture has generated significant contributions in the direction and conduct of the human being. The continuous search of the relationship between the dispositions and the management in an organization implies a feasible process of culture formed by beliefs, values, myths, shared feelings and way of acting where union and collaboration is fundamental for the achievement of a pleasant environment, a key factor for the success of public and private institutions.

Organizational culture is a set of paradigms, which are formed throughout the life of the organization as a result of the interactions among its members, of these with the structures, strategies, systems, processes and of the organization with its environment, from which a set of references is formed, which will be valid as they guarantee the efficiency and effectiveness of the organization (Alabart, 2014).

The organizational culture is linked to different factors that contribute to the strengthening of institutions putting into practice the knowledge acquired in terms of procedures, rules and policies, demonstrating skills and dexterity in the activities that are developed. Educational institutions should be oriented towards the management of the organizational culture that will allow it to be sustainable in a changing world.

Public institutions should focus their efforts on finding solutions to the different problems that arise in the internal part, motivated among other causes by deficiencies in terms of leadership, communication, teamwork, decision making, and the poor implementation of policies and current regulations, among other aspects, which induces a division among the public servants of the different areas. That is to say that the management of the organizational culture should lead the educational institutions to include improvements in the processes that are developed, promoting the permanent training of the personnel, and establishing more efficient ways of managing this activity, always in order to satisfy the internal and external customer, within the framework of university social responsibility as it has been studied by Faría, Salazar and Castellano (2017).

This paper considers the conceptual analysis of organizational culture management models that could be applied in public institutions of the education sector. 


\section{ANALYSIS OF THE DEFINITION OF MANAGEMENT OF ORGANIZATIONAL CULTURE AND MODELS OF MANAGEMENT OF ORGANIZATIONAL CULTURE}

Culture is presented in all human activity, so it is necessary to inquiry about the management of organizational culture (OC), which will strengthen values, communication, decision making, performance, among others, in the operation of public education institutions.

\subsection{Management of Organizational Culture}

The management is characterized by a broad view of real possibilities of an institution, which allows to solve a problem or achieve a specific purpose. That is, it is the set of integrated actions for the achievement of a goal at a certain time; it is the main task of the administration and an intermediate link between planning and the specific objectives to be achieved in an institution.

Mintzberg (1984) and Stoner (1996) have defined that the term management is the disposition and organization of the resources of an individual or group to obtain the expected results. It could be generalized as the art of participatory anticipation of change, with the purpose of permanently creating strategies to guarantee the desired future of an organization; it is a way of aligning efforts and resources to achieve a certain goal.

The traditional meaning of the concept of management is directly related to that of administration, and means "to make conducive diligences to the achievement of some objectives" (Ramírez, 2005).

García (2006) indicated that the management of the OC is conceived as a process that takes place in a planned and unidirectional manner, that is, the values and institutional policies determined by management are disseminated throughout the organization, with the intention that these are internalized by the people and in this way they build commitment and organizational identity on behalf of the employees.

$\mathrm{CO}$ is fundamental for the management of knowledge in any type of institution, which is generally understood as the set of values, principles, ideas, customs, habits and traditions that are shared by all people who are part of an organization. Toca (2009) defines the organizational culture as "a shared social understanding, product of assumptions and common visions among the members of an organization", and different levels of culture are distinguished: basic assumptions, values or ideologies, artifacts (slang, stories, rituals and decoration, values and ideologies) and practices.

Naranjo, Jiménez and Sanz (2012) expressed that the organizational culture is considered as one of the key elements in innovation, both in its improvement and in its inhibition. Organizational culture is considered in literature as one of the factors that can most stimulate innovative behavior among the members of the 
organization. Robbins and Judge (2013) exposed that it is a "Perception shared by all the members of the organization: System of shared meanings". Likewise, culture helps the organization to distinguish itself from another; implements the sense of identity and unity; focuses on the interest in the majority rather than in self-interest; strengthens the stability of the social system as a social glue that holds the organization together; it serves as a control mechanism and shapes the attitudes and behavior of employees.

Whatever the theoretical perspective adopted on the conception of organizational culture from the rational aspects or from the emergent ones, it is necessary to take into account that in order for the management systems in organizations to be conducted with greater probability of success, it must always be based on the characterization or analysis of culture; that is, doing a study to know and understand the aspects that define it. Likewise, a comparison of these results is made with the characteristics of the management systems in order to identify the degree to which the factors of culture and management systems are coherent with each other (Vesga, 2013).

The management of organizational culture is the formula of the companies of great prestige for these times, is the way in which they are achieving a differentiating factor, which brings results of impact on these. In this way we could say that a solid and integrated culture; consistent with the objectives and the environment, it makes the difference between a high performance company and a low performing one (Bernal, 2015).

Organizational culture influences the efficiency of knowledge management, because culture acts as a mediator between individual knowledge and that of the organization, and also generates spaces for social interaction that allow the creation, exchange and application of knowledge. A knowledge-oriented organizational culture will remain if it is adequately supported by top management since capturing and sharing knowledge requires time and continuous support (Rojas and Vera, 2016).

It is considered that culture is created as a variable that can be transformed through techniques, with the purpose of improving the behavior of people with integral objectives. Adequate understanding provides a strategic vision for change through the study of each institutional reality, so that the relationships of the internal and external environment will improve, applying the different definitions that strengthen the knowledge and behavior of the individual. In this way it could be stated that the management is oriented to the OC in order to strengthen the institutions through strategies and standards, which should be applied for a better functioning, nevertheless, it should create awareness and strategic commitment in each one of the members if they want to achieve institutional purposes. 


\subsection{Models of Organizational Culture}

Public institutions must take into account an organizational culture that allows them to face the challenges and adapt to the changes, in such a way that the objectives are achieved. So it is important for institutions to acquire knowledge of the type of culture and characteristics that predominate within them, allowing them to improve the performance of public servants.

The management has two perspectives that are part of the organizational culture approach. The performance-oriented perspective - processes and the humanoriented perspective - values (Aktouf, 2002; Morcillo, 2006; Nikandrou, et. al., 2008).

On the one hand, performance orientation is the degree to which an organization encourages and rewards the members of the group in order to achieve high standards, better performance and operational excellence. This approach sees culture as a tool to encourage commitment and achieve objectives (House et al., 2004; Soemaryani and Rakhmadini, 2013). On the other hand, the orientation to the human being is the degree to which an organization encourages and rewards the members of the group for their way of being and good treatment towards others. Corporate values are proposed by the organization and are aligned with the personal values of the members of the organization (Qubein, 1999; House, et al., 2004). The following is a summary of some models related to these approaches.

Schein (1990) defined the main characteristics of the existing culture in an organization, distinguishing three levels: artifacts, values and assumptions:

- Artifacts: This level is constituted by architecture, technology, communication, clothing, among others. At this level, the analysis is difficult, because the data are easy to obtain but difficult to interpret.

- Values: Basically refer to the beliefs of the working group that are established from the values that exist in the organization, which determine whether the culture contributes or hinders the achievement of goals and objectives.

- Assumptions: This level describes how individuals in the organization think they feel and act. It is composed of five dimensions: the relationship of the organization with the environment, the nature of reality and truth, human nature, the nature of human activity and the nature of human relationships. This model has limitations in the connections between artifacts, values and cultural assumptions.

Hatch (1993) makes reference to the model of Schein (1984), and in turn introduces a new element to this model: the symbols along with the symbolicinterpretative approach. It also describes as processes the relationships between cultural elements (artifacts, values, assumptions and symbols); in this way, it demonstrates that these cultural elements are related in a dynamic and circular 
process in the two moments of culture: stability and change. The model tries to articulate the processes of exposure, performance, representation and interpretation, and argues that none of these processes can be sustained in isolation.

Trompenaars and Wooliams (2003) define that the culture in an organization is modeled not only by the technologies and markets that influence it, but also by the cultural preferences of leaders and employees. There are three aspects of the organizational culture: the general relations between the employees and the organization, the system of hierarchical authority that determines the superiors and subordinates, and the general views of the employees about the destiny of the organization, its purposes and its goals. . This model has two dimensions that allow to distinguish the organizational culture, which generates four quadrants: equality - hierarchy and orientation to the person - orientation to the task. Four types of organizational culture are also defined, which vary considerably regarding the ways of thinking, learning, motivating, resolving conflicts and rewarding. This categorization helps organizational analysis, but it also has the risk of typifying or stereotyping to simplify something that is complex. The four types of organizational culture are the family, the Eiffel Tower, the guided missile and the incubator.

Cameron and Quinn (2011) proposed a methodology based on the Competency Values Framework model. The purpose of this model is to diagnose the culture of an organization and facilitate the change of it. The same ones that identified four types of dominant cultures: clan, adhocracy, hierarchical, and market. In this type of culture the organization is oriented to the results, worrying about doing a well done job. People are competitive, leaders are demanding and competitive in turn. Competitiveness and productivity in market-oriented organizations are achieved through a strong emphasis on market participation, positioning and control. The model also shows if the organization has predominant characteristics in terms of the degree of flexibility facing environmental changes on the part of its members; or if in its case the organization is oriented towards stability and control while facing changes.

The proposed models refer to an organizational culture aimed at performance, cultural changes, technologies, which has allowed private and public companies to improve their processes. So it is necessary to indicate that they have dimensions according to the environment where they are developed. However, they have limitations in terms of methodology, instruments for diagnosis, levels at which culture manifests, that is, management is not considered, it is only based on models of organizational culture. 


\section{MANAGEMENT OF ORGANIZATIONAL CULTURE IN PUBLIC INSTITUTIONS OF THE EDUCATIONAL SECTOR}

The organizational culture within the institutions is an important aspect according to the management that is developed, which integrates the actors for a better functioning of these institutions. The management is related to the administration and transformation of the processes based on the policies, norms, values, which will allow the strengthening and development of the same.

North (1990) defines institutions as the rules of the game that shape human interaction in a society. The components of institutions, the rule and the imposition or sanction, to define institutions as the rules commonly known to structure repetitive interaction situations followed by a mechanism of application and sanction that ensures that the failure to comply with the rules component is sanctioned, are studied by some authors, included Aira (2016). The function of institutions is to reduce uncertainty through important elements such as securing property and rights contracts. Institutions provide the structures to define and limit the set of choices of individuals, reducing uncertainty by regulating a legal environment of property rights, the establishment of social conventions and norms, the concern for economic development centered on institutional development.

To establish the difference between an institutional order and an organizational order, Dove (2001) argued that both institutions and organizations are made by humanity. But they have a totally different nature, and they require different mental processes to study, understand and change them. Organizations are components of the social order, while institutions are that order. Institutions are abstract entities, and their purpose is to facilitate exchanges between organizations or individuals, allowing them to realize specific objectives. That is, institutions are like the rules of the game that organizations are playing.

The most developed societies have generated their own conditions for the institutional transformation that implies the structuring rules of collective action, mental models, values, attitudes and capacities, and balances of power. This can only result from the social learning process which usually can only happen incrementally. The correlations on which the institutional transformation depends are too complex to permit its valid planning. It is this complexity that not only makes the temporary programming of changes very difficult but also will almost inevitably produce unintended transformations and unforeseen effects. The institutional transformation and unforeseen effects. Institutional transformation can not be the fruit of human will alone, as the constructivist instrumental rationalism continues to pretend (García, 2015). In case of universities, the change must occur in the face of quality models demands and the changing needs for customers (Alvarado and Barba, 2016).

Change and institutional transformation modify the character and integrity of organizations. The institutions are the set of norms, policies that are related to the forms of interaction of the actors and of the organizations that make up a political 
system, so the changes are related to the norms that condition the forms of access to power and the relations of citizens with the rulers.

Calero (2005) expressed that institution is the articulated set of actions of conduction of an educative center to be carried out with the purpose of achieving the objectives contemplated in the institutional educational project.

The public institutions of the education sector in Ecuador must be able to promote values that allow demonstrating a good performance according to the activities developed by public servants, so that there is a change and transformation of them must apply the rules and policies that govern in the entities, for what is generated a management of organizational culture that transmits a sense of union between the members of those institution. The above will be linked to other organizational measures that should be taken to improve efficiency and effectiveness parameters in management (Flores, et al., 2014).

Regarding the concept of institution Meza (2007) indicated that it is remarkable how the expression can become general, if one considers that companies are also focused on the public, that is, on people. However, in the middle, we try to differentiate it from what is a company, more by its origin and purpose, because in these cases both have certain differences. While the company seeks profit and obtain maximum economic gain through the production of goods or services for the general public or its customers; the institutions try to provide a good or service to the general public, without profit motive and, primarily, because they are part of a state, to satisfy the needs of the people.

Based on the various definitions that have been revised about institution, it can be indicated that they are applicable to public institutions according to the following reasons:

1. Set of functional dependencies that constitute the public sector is an organization, and therefore, can be approached for study from the theories of administration.

2. As an organization, it is characterized by the following structural components: mission, culture, government, administration and financing.

3. All groups of people who meet with some objective, define certain uses and customs and institutionalize criteria on what is acceptable and unacceptable. The set of these elements configures mental models, concepts, habits and forms of relationship that can be summarized in the category of analysis: organizational culture 
In a general way it can be said that the organizational culture influences an institution basically on:

1. the behaviors of human beings;

2. commitment to the institution;

3. the work of the institution, performed invisibly on the methods and techniques of managing the organizational culture;

4. how to deal with problems and how to provide solutions;

5. the appreciation of the institutional context by those involved;

6. attitude towards changes.

It is necessary to understand the high level of impact and the influence that the organizational culture has on the institutions, it is necessary to clarify the meaning of the set of analytical qualities that has been used.

Felcman, Blutman and Méndez (2001) consider that culture is composed of elements and manifestations both visible and conscious as invisible and unconscious, including within the organizational culture those related to labor values, cultural types and basic assumptions.

From the above, it can be concluded that organizational culture is essential within public institutions because it involves society, recognizing a dynamic learning process according to values, beliefs, rules, procedures, language, ritual and ceremonies, which strengthens relations between public servants and community. The culture determines the way an organization performs, it is reflected in the strategies, structures, methods and systems according to what is established by each institution.

\section{MANAGEMENT IN THE PUBLIC INSTITUTIONS OF THE ECUADOR EDUCATIONAL SECTOR}

The Constitution of the Republic of Ecuador (2008) in Article 227 states that "Public Administration constitutes a service to the community that is governed by the principles of effectiveness, efficiency, quality, hierarchy, decentralization, coordination, participation, planning, transparency and evaluation", it also establishes the Technical Standard of Restructuring of Institutional Public Management (Ecuador, 2011). Under this approach, the success and organizational vitality of institutions depend on the development of appropriate cultures and values that contribute to new forms of administration and organization.

Under the previous legal framework, most of the processes were concentrated in the central building of the Ministry of Education, which made it very difficult to provide timely responses to local needs throughout the country. In the new legal framework, it is defined that the National Educational Authority is made up of 
four levels of management: one of a central nature and three of deconcentrated management, which correspond to the zonal, district and circuit levels (Article 25 of Organic Law on Education and Interculturality). In this context, "deconcentration" means that the central level retains the power to create public policies, but that deconcentrated levels are in charge of implementing them. By decentralizing the management of the Ministry, two main objectives are achieved:

1. The attention of the State is brought closer to citizens, which ensures, in a timely and strategic manner, greater agility, efficiency and effectiveness in educational services.

2. The educational offer is rationalized and reorganized to guarantee complete and relevant educational services in each circuit. All this also allows to achieve greater transparency for all processes.

The new educational legal framework establishes that education is a necessary condition for equal opportunities and to achieve the Good Living society. In this sense, education is conceptualized once again, which can no longer be a privilege of a few, but "a right of people throughout their life" and therefore "an inescapable and inexcusable duty of the State", and "a priority area of public policy and state investment" (Article 26 of the Constitution). From all of the above it is inferred that education must respond "to the public interest" and must not be "at the service of individual and corporate interests" (Article 28 of the Constitution).

The Republic of Ecuador within its current regulations contemplates the following axes:

- Restoration and rationalization of the institutional structure of the Executive Function.

- Development of new management models of public institutions for the provision of services to clients.

- Deconcentration and decentralization of the State, both in the analysis and definition of the areas of action of state institutions, and in the rethinking of the mechanisms, processes and procedures through which public actions are carried out, the relationship with the Territories and the functional differentiation between institutions must be concretized in localized public interventions and in new state institutions in the territories.

The main purpose of public administration is to change the attitudes of actors responsible for the management of the public, political agents, public servants, community and social leaders. The trend to the client, corporatism and dependency are predominant features of the mentality of the bureaucracy of the last century that must be fought; and that are the result of a history of centralism, 
dependence, patrimonial patterns and client trends, far from a just and selfsustainable development project for which the country has bet.

The public administration seeks to increase the ethical values of public servants, encouraging behaviors that are directed to carry out their work with the best willingness to serve, to use rationally and economically the resources of the State, to seek the highest efficiency and quality in their work, to improve their own professional competence, to practice good faith in their relationship with citizens and to help create a good working environment.

In general, the need for Ecuadorian public universities to raise the management level, based on fundamental aspects of the quality approach for internal and external clients (Cárdenas, 2016), which will allow them to reach international standards. This analysis has generally focused on value-adding processes, such as the training of professionals and research (Véliz, Quindemil and Rumbaut, 2015). At the same time, it is recognized as a challenge that, in these aspirations, the organizational culture allows to reach the expected levels in the "academic and administrative quality of public university" (García, et al., 2014).

\section{CONCLUSION}

The organizational culture within the public institutions of the education sector influences their values, behaviors, policies, norms, which allows improving the behavior of public employees.

The organizational culture management models reported in the literature are basically oriented to private and public business sector, which are not easily adaptable to the education sector.

Ecuador and its policies developed for public educational institutions do not refer to the management of organizational culture, which causes the dismantling of the planning, organization, execution and control processes that are carried out within them.

There are no reference to management models of organizational culture oriented to provide services in education sector, so it would be novel to design and implement a model of this type in the Republic of Ecuador.

\section{ACKNOWLEDGMENTS}

This article was written with the endorsement of the Southern State University of Manabí and the Pinar del Río University. 


\section{REFERENCES}

Aira, M.R., 2016. Las instituciones y su incidencia en el comportamiento organizacional. Revista Científica Electrónica de Ciencias Gerenciales, 33(11), pp.99-111.

Aktouf, O., 2002. El simbolismo y la cultura organizacional. De los abusos conceptuales a las lecciones de campo. Ad-Mninister, 1, pp.63-93.

Alabart, Y., 2014. Modelo, metodología y herramientas para el diagnóstico de la cultura organizacional. Cali: Ponencia presentada en el III Congreso Internacional Red Pilares.

Alvarado, M. and Barba, M., 2016. Gestión del talento humano e innovación de la enseñanza y el aprendizaje. Bloomington: Palibrio.

Bernal, R.M., 2015. Gestión de la cultura organizacional de Servicio en el sector público como ventaja competitiva para el país. [pdf] Bogotá D.C: Universidad Militar Nueva Granada Facultad de Ciencias Económicas. Available at: $<$ http://repository.unimilitar.edu.co/bitstream/10654/7897/1/BernalGarciaRosaE milia2015.pdf $>$ [12 March 2018].

Calero, M., 2005. Gestión Educativa. Lima: Ediciones Abedul.

Cameron, K.S. and Quinn, R.E., 2011. Diagnosing and changing organizaional culture: Based on the competing values. San Francisco: Jossey-Bass.

Cárdenas, A., 2016. Calidad en la gestión universitaria ecuatoriana: Una búsqueda latente de eficiencia educativa. Multiciencias, 16(2), pp.194-201.

Dove, S., 2001. Las decisiones políticas: Instituciones vs. organizaciones. PNUD: Instituto Internacional de Gobernalidad.

Ecuador, 2008. Constitución de la República del Ecuador. Quito: Asamblea Constituyente.

Ecuador, 2011. Norma Técnica de Reestructuración de la Gestión Pública Institucional. Quito: Secretaría Nacional de la Administración Pública.

Faría, M.C., Salazar, C. and Castellano, M.I., 2017. Endomarketing: Estrategia dinamizadora para la responsabilidad social del sector universitario. Espacios, 36(1), pp.6-21.

Felcman, I., Blutman, G. and Méndez, P.S., 2001. Construcción de un marco teórico para el análisis de la cultura organizacional. Argentina: Universidad de Buenos Aires.

Flores, A., Lavín, J.M., Calle, X. and Alvarez, E., 2014. Buscando la excelencia educativa: Gestión de procesos académicos y administrativos en Instituciones Públicas de Educación mediante BPM. MASKANA, 5(especial 2014), pp.199209.

García, C.M., 2006. Una aproximación al concepto de cultura organizacional. Universitas Psychologica, 5(1), pp.163-174. 
García, M.A., González, R., Aldrete, MG., Acosta, M. and León, SG., 2014. Relación entre Calidad de Vida en el Trabajo y Síntomas de Estrés en el Personal Administrativo Universitario. Ciencia \& trabajo, 16(50), pp.97-102.

García, M.E., 2015. Enfoque estratégico relacional-participativo, constructivista y complejo como dinamizador de la vinculación universidad-sociedad. Estrategia y gestión universitaria, 3(2), pp.45-55.

Hatch, M.J., 1993. Las dinámicas de la cultura organizacional. Revista de la Academia de Gerencia, 18(4), pp.2-5.

House, R.J., Hanges, P.J., Javidan, M., Dorfman, P.W. and Gupta, V., 2004. Culture, leadership, and organizations: The globe study of 62 societie. Thousand Oaks, CA: Sage Publications.

Meza, M.J., 2007. Incidencia de las estructuras organizacionales en la productividad del sector público. Quito: Tesis de maestría.

Mintzberg, H., 1984. La estructuración de las organizaciones. Barcelona: Ariel.

Morcillo, P., 2006. Cultura e innovación empresarial: La conexión perfecta. Madrid: Paraninfo.

Naranjo, J., Jiménez, D. and Sanz, R., 2012. ¿Es la cultura un determinante de la innovación en la empresa? Cuadernos de economía y dirección de empresa, [ejournal] 15(2), pp.63-72. https://doi.org/10.1016/j.cede.2011.07.004.

Nikandrou, I., Apospori E., Panayotopoulou, L., Stavrou, E.T. and Papalexandris, N., 2008. Training and firm performance in Europe: The impact of national and organizational characteristics. The International Journal of Human Resource Management, [e-journal] 19(11), pp.2057-2078. https://doi.org/10.1080/ 09585190802404304.

North, D., 1990. Institutions, institutional change and economic performance. Cambridge: Cambridge University Press.

Qubein, N., 1999. Action takers. Executive Excellence, 16(10), pp.4-4.

Ramírez, C., 2005. Fundamentos de Administración. Bogotá: Textos Universitarios.

Robbins, S. and Judge, T., 2013. Organizational behavior. 15th ed. Estados Unidos: Pearson Prentice Hall.

Rojas, G.E., and Vera, M.A., 2016. Cultura organizacional en la gestión del conocimiento. Apuntes de Administración, 1(1), pp.50-59.

Schein, E.H., 1984. Coming to a new awareness of organizational culture. Sloan Management, 25(2), pp.3-16.

Schein, E.H., 1990. Organizational culture. American Psychologist, 45, pp.109119. 
Soemaryani, I. and Rakhmadini, D., 2013. Work life balance and organizational culture in creating engagement and performance. International Journal of Innovations in Business, 2(4), pp.327-349.

Stoner, J., 1996. Administración. México: Prentice-Hall Hispanoamericana.

Toca, C.E., 2009. Asuntos teóricos y metodológicos de la cultura organizacional. Civilizar, 9(17), pp.117-136.

Trompenaars, F. and Wooliams, P., 2003. Business across cultures. Minnesota: Capstone.

Véliz, V.F., Quindemil, E.M. and Rumbaut, F., 2015. Gestión de la calidad en la Educación Superior: el proceso formativo en la universidad ecuatoriana. Journal of Education and Human Development, [e-journal] 4(4), pp.188-194. http://dx.doi.org/10.15640/jehd.v4n4a22.

Vesga, J.J., 2013. Cultura organizacional y sistemas de gestión de la calidad: una relación clave en la gestión de las instituciones de educación superior. Guillermo de Ockham, 11(1), pp.89-100.

\section{ABOUT AUTHORS}

Mayra Mercedes Marcillo Indacochea - Economist. Master in Educative Management (Universidad Estatal del Sur de Manabí). PhD student of the Economic and Managerial Science Doctoral Program of Universidad de Pinar del Río, Cuba. Martí end Street 270, Pinar del Río, Pinar del Río, Cuba, e-mail: maymar811@hotmail.com.

Raúl Ricardo Fernández Concepción - Chemical Engineer. Doctor in Technical Sciences (Universidad de Humboldt, 1987). Professor of the Forestry Studies Center, Universidad de Pinar del Río, Cuba. Martí end Street 270, Pinar del Río, Pinar del Río, Cuba, e-mail: raulricardo@upr.edu.cu.

Angie Fernández Lorenzo - Bachelor in Economy. Doctor in Economic Sciences (Universidad de Pinar del Río, 2011). Professor of the Department of Economics, Management and Commerce Sciences, Universidad de las Fuerzas Armadas ESPE, Ecuador. Ave. Gral, Rumiñahui s/n, Rumiñahui, Pichincha, Ecuador, e-mail: aafernandez2@espe.edu.ec.

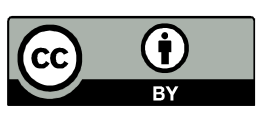

(C) 2018 by the authors. Submitted for possible open access publication under the terms and conditions of the Creative Commons Attribution (CC-BY) license (http://creativecommons.org/licenses/by/4.0/). 